\title{
Exploration in the Netherlands, 1987-2012
}

\section{H. Kombrink ${ }^{1,2,{ }^{*}}$, J.H. ten Veen ${ }^{1} \&$ M.C. Geluk ${ }^{3}$}

1 TN0 - Geological Survey of the Netherlands, P.0. Box 80015, 3508 TA Utrecht, the Netherlands.

2 Present address: Total E\&P UK, Crawpeel Road, AB12 3FG, Aberdeen, United Kingdom.

3 Shell Development (Australia) Pty Ltd, 2 Victoria Avenue, Perth WA 6000, Australia.

* Corresponding author. Email: henkkombrink@hotmail.com.

Manuscript received: January 2012, accepted: April 2012

\begin{abstract}
Following a time of expansion of the oil industry, the period 1987-2012 and especially the second half of it reflects a diversification of exploration activities in the Netherlands. In addition to the ongoing discovery of classical hydrocarbon reservoirs, successful attempts have been made to explore deep geothermal energy. Shale gas and Coal Bed Methane received interest in the Netherlands too but so far no wells have been drilled in order to test the potential. Storage of gas and liquids has been introduced and salt mining more or less continued without many changes. In terms of drilling activity, the last 25 years show a decreasing trend and the discovered volumes are smaller. Testing of new play concepts was either successful (shallow gas) or not (Dinantian) and sometimes an unexpected discovery was made (Triassic Fat Sands). New techniques proved older fields to be exploitable again, e.g. redevelopment of the Schoonebeek Field. Therefore, despite a decline in number of wells drilled and reserves added, the diversification of use of the subsurface will guarantee ongoing exploration.
\end{abstract}

Keywords: exploration, Netherlands, oil, gas, subsurface, geothermal, salt

\section{Introduction}

The Netherlands can be considered a country with rich and varied subsurface resources. Gas is the most important resource, with gas volumes to date comprising some $4500 \mathrm{Bcm}$ of which the Groningen Field contains $2750 \mathrm{Bcm}$. Of the $1750 \mathrm{Bcm}$ still to be produced $1100 \mathrm{Bcm}$ resides in the Rotliegend play, with the Triassic being the second play containing some $250 \mathrm{Bcm}$. The remaining $400 \mathrm{Bcm}$ are distributed over various other plays (Carboniferous, Zechstein, Jurassic, Lower Cretaceous, Chalk and Cenozoic). 1 Billion barrel of recoverable oil has been proven, of which over $25 \%$ is in the Schoonebeek Field. In addition to hydrocarbons, rock salt, magnesium salts and geothermal energy are produced from our subsurface and rich coal layers are omnipresent. Storage of natural gas, oil and nitrogen in depleted reservoirs and salt caverns is another recent development (Figs 1 and 2).
Various papers already provided an overview of the hydrocarbon, salt and coal exploration history in the Netherlands. The most important are Brouwer \& Coenen (1968), Knaap \& Coenen (1987), Glennie (2001) and Geluk \& De Jager (2012). The interested reader is referred to these papers and the references therein for further details on the early periods. The starting point for this paper is 1987 (the publication of Knaap \& Coenen, written to commemorate the $75^{\text {th }}$ anniversary of the Royal Society of Geologists and Mining Engineers, KNGMG). In the last 25 years we have witnessed many changes regarding the place hydrocarbon exploration and production occupy in our country. Since 1987, a total of 473 hydrocarbon exploration wells were drilled (141 onshore, 332 offshore) which have discovered 184 new fields conforming to a success rate of $59 \%$. These new fields, and volume revisions of discovered fields, increased our total gas volumes with some $700 \mathrm{Bcm}$. Despite the fact that the Netherlands are a mature area, still new plays can be discovered - as exemplified by the Triassic Solling play 

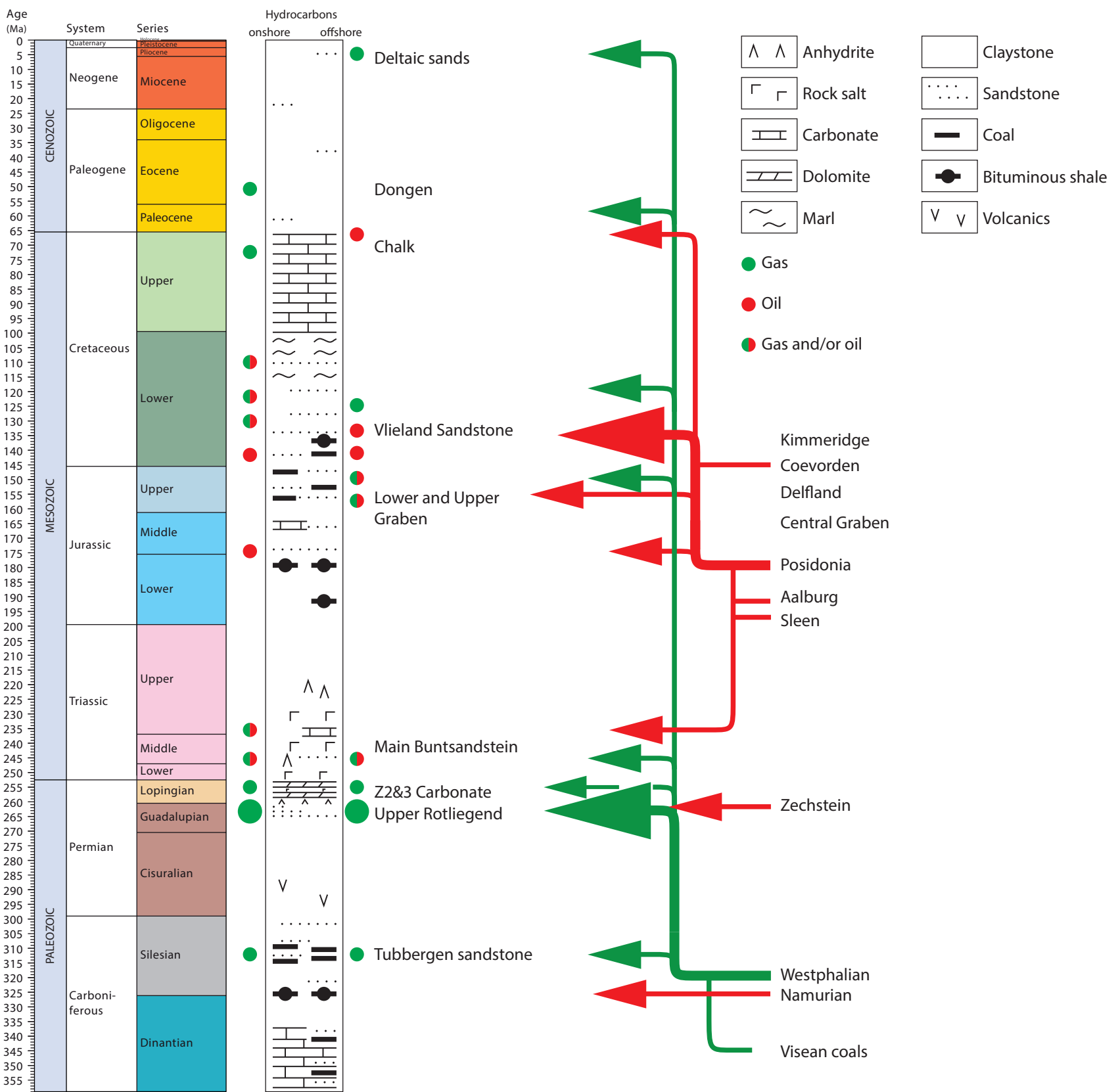

Fig. 1. Overview of the petroleum systems in the Netherlands (modified after De Jager \& Geluk, 2007).

(see De Jager, this issue). Other new play concepts, however, were tested but unsuccessful (Dinantian, see below). Some of the already proven plays still remain immature and may contain significant undiscovered hydrocarbon potential (10's to 100 $\mathrm{Bcm})$; the Upper Jurassic - Lower Cretaceous is one of these plays (see Munsterman et al., this issue).

The hydrocarbon volumes discovered during the last 25 years are not distributed evenly over all hydrocarbon plays - with $350 \mathrm{Bcm}$ the Rotliegend play saw the largest increase, followed by the Triassic play with some $150 \mathrm{Bcm}$. The other plays are lagging far behind - the Carboniferous initial reserves increased with some $25 \mathrm{Bcm}$, the Cenozoic with $15 \mathrm{Bcm}$ and in the Upper Jurassic - Lower Cretaceous and Zechstein plays $10 \mathrm{Bcm}$ and $5 \mathrm{Bcm}$ were added respectively.
The level of exploration activities showed a marked decrease. Initially the number of exploration wells drilled annually was as high as 40 or even 50, but since the mid 1990's this figure gradually decreased to 10 to 20 per year. Onshore drilling activity showed the strongest decrease - in some years just one single well was drilled.

An almost blanket cover of 3D seismic data has been acquired, processed and interpreted over the prospective areas of the Netherlands (see Kombrink et al., this issue). Hand in hand with the denser data coverage, new techniques emerged such as basin modelling (see Nelskamp et al., this issue; Abdul Fattah et al., this issue), 3D seismic interpretation (see Benvenuti et al., this issue; Ten Veen et al., this issue), subsurface temperature assessments (see Bonté et al., this issue) and pressure prediction 

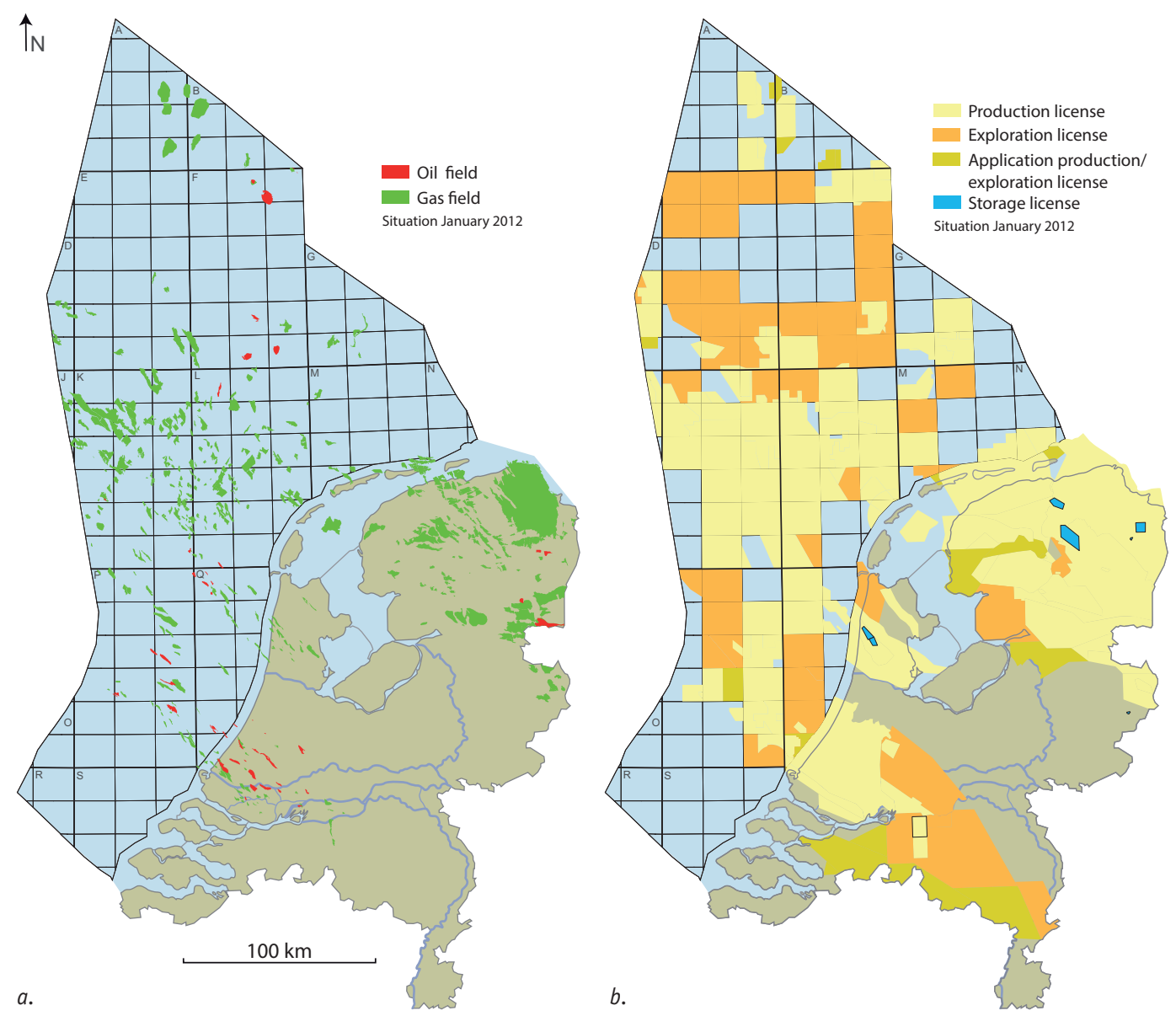

a.
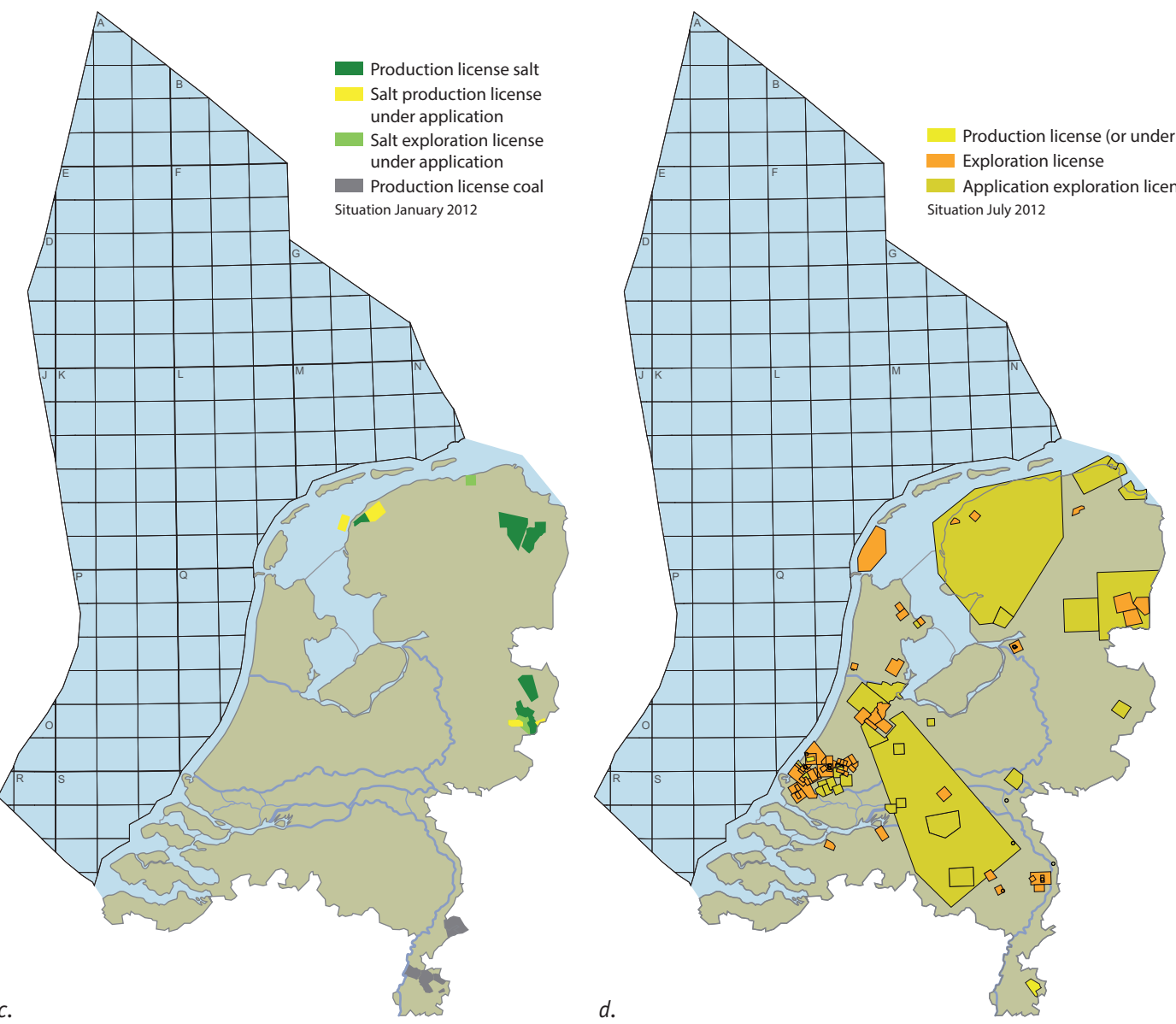

Fig. 2. License situation in the Netherlands. a. Oil and gas fields; $b$. Hydrocarbon exploration and production licenses; $c$. Coal concessions in the SE of the country (grey) and salt production licenses; d. Geothermal exploration and production licenses. Source: www.nlog.nl. 
(see Verweij et al., this issue). This has significantly increased our understanding of the subsurface. The recent increase in interest in geothermal energy kickstarted a series of studies aimed at mapping potential reservoirs and estimating resources (see Kramers et al., this issue; Van Wees et al., this issue; Pluymaekers et al., this issue).

Data availability improved significantly. Since the new mining law was introduced in the Netherlands (2003), proprietary well and seismic data are made available online (www.nlog.nl) only five years after acquisition, instead of 10 years previously. Information regarding our subsurface became available to the general public through a variety of publications (Wong et al., 2007; Doornenbal \& Stevenson, 2010; Duin et al., 2006 and the mapsheets of the deep subsurface of the Netherlands, published by TNO - Geological Survey of the Netherlands).

In summary, the last 25 years are characterised by a marked diversification of the use of our subsurface - from exclusively extraction of resources 25 years ago to a multitude of applications today. This paper gives an overview of these developments, starting at the discussion per hydrocarbon play system (ranked according to discovered volume) to an overview of developments in geothermal energy.

\section{Hydrocarbons}

\section{Rotliegend - Netherland's bread and butter play}

Much has been written about the Rotliegend play which, in terms of discovered volumes, is the top ranking play in the Netherlands. The play concept is relatively simple: gas charged from the coal-bearing Carboniferous is trapped in dune and wadi sandstones of the Permian Rotliegend, and sealed by the Upper Permian Zechstein salt (De Jager \& Geluk, 2007 and references therein; Grötsch \& Gaupp, 2011). The Rotliegend play fairway is delineated by the pinch-out of sandstone to the north and the presence of the Zechstein salt seal to the south (Fig. 3).

In the late 1980 s, the conventional belief was that most of the Rotliegend fields had been discovered (De Jager \& Geluk, 2007). This belief, however, turned out to be false and in the Lauwerszee Trough and on the Cleaverbank Platform significant volumes have been found since (Fig. 4). In the Lauwerszee Trough in the NE onshore Netherlands, remaining prospectivity was thought to be limited in 1987. Three prospects were identified in the area, of which Grijpskerk was the largest with a UR of 1-2 Bcm. The exploration well Grijpskerk-1 was a surprise: it found gas but the Gas Water Contact $70 \mathrm{~m}$ deeper than expected. This was caused by the Ten Boer Claystone Member acting as a lateral seal in fault juxtaposition. The Grijpskerk discovery (1990) was followed by Sebaldeburen (1990), Munnekezijl (1992), Moddergat (1995) and Metslawier-Zuid (2011), adding over $150 \mathrm{Bcm}$ of reserves in this area (De Jager \& Geluk, 2007). Another successful area was the Cleaverbank Platform in the NW offshore, where the limits of the sandstone fairway shifted

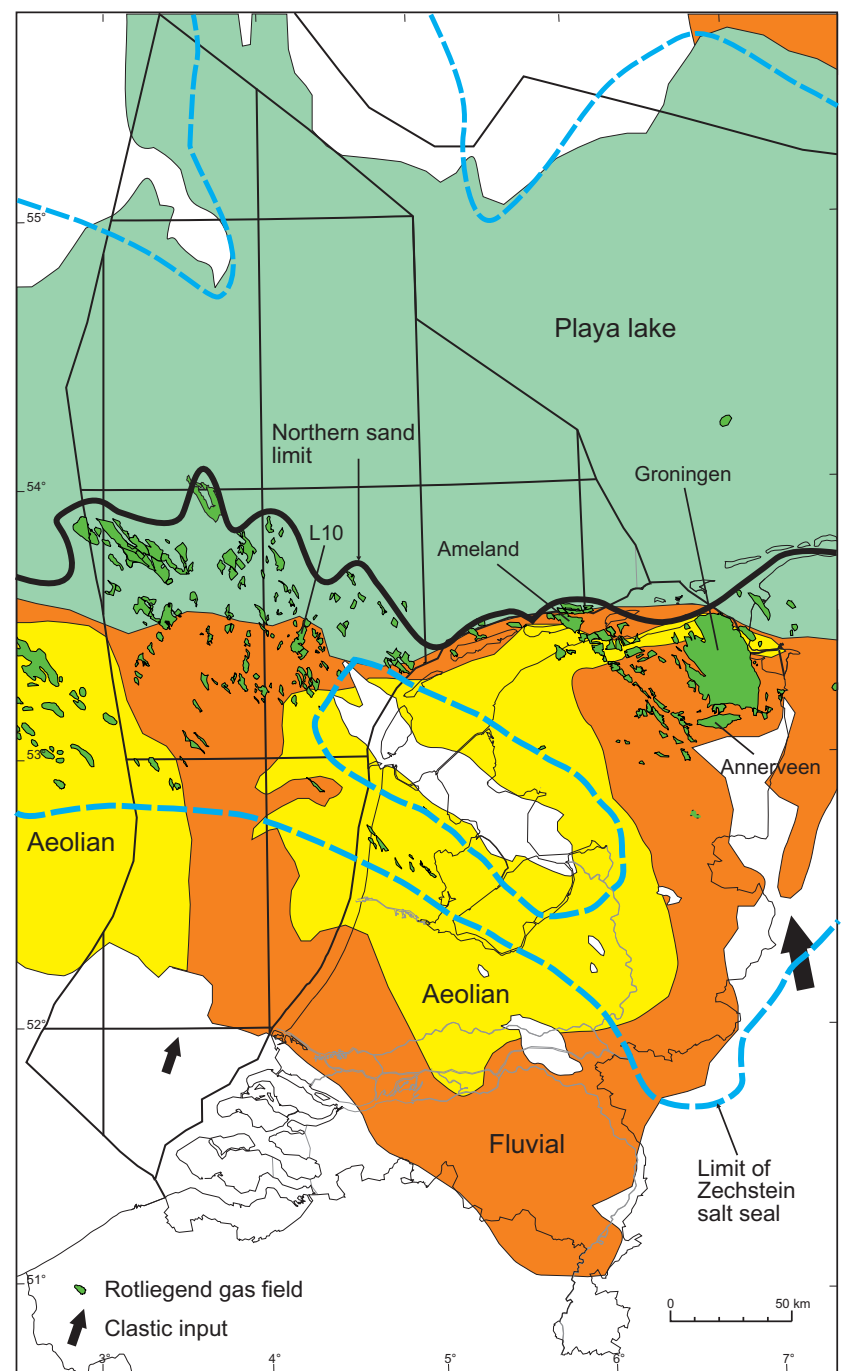

Fig. 3. Upper Rotliegend play map. The gross depositional environments at approximately Upper Slochteren level are shown. The gas fields located in the area of playa-lake facies are in older, basal Rotliegend sandstone reservoirs. The southern limit of Rotliegend gas fields is controlled by the southern extent of the Zechstein top seal (blue line). After De Jager \& Geluk (2007).

considerably northwards: the discovery of - amongst others K2b-A (1987), J3-1, K1-3, K3-1, F16-E (2001) and F16-P (2004) changed our understanding of the Lower Slochteren distribution and extended the prospective Rotliegend area further north. At the same time, known heartlands continued to deliver as well. In the western offshore discoveries were made in the $\mathrm{J}, \mathrm{K}$ and $\mathrm{L}$ quadrants (e.g. K15-FK and L15). Around the Groningen Field a number of successful discoveries were made in small fault blocks (e.g. Witten, Witterdiep, Faan and Harkema). The latter fields are not adding significant volumes, but surely deliver value.

Current interest for the Rotliegend play comprises High Pressure / High Temperature (HPHT). In the L5-10 well (5450 m TD, 1023 bar and $180^{\circ} \mathrm{C}$; Fig. 4) a Rotliegend discovery was announced recently by GdFSuez. This type of discoveries might open a new fairway of deep Rotliegend (Lower Slochteren) 

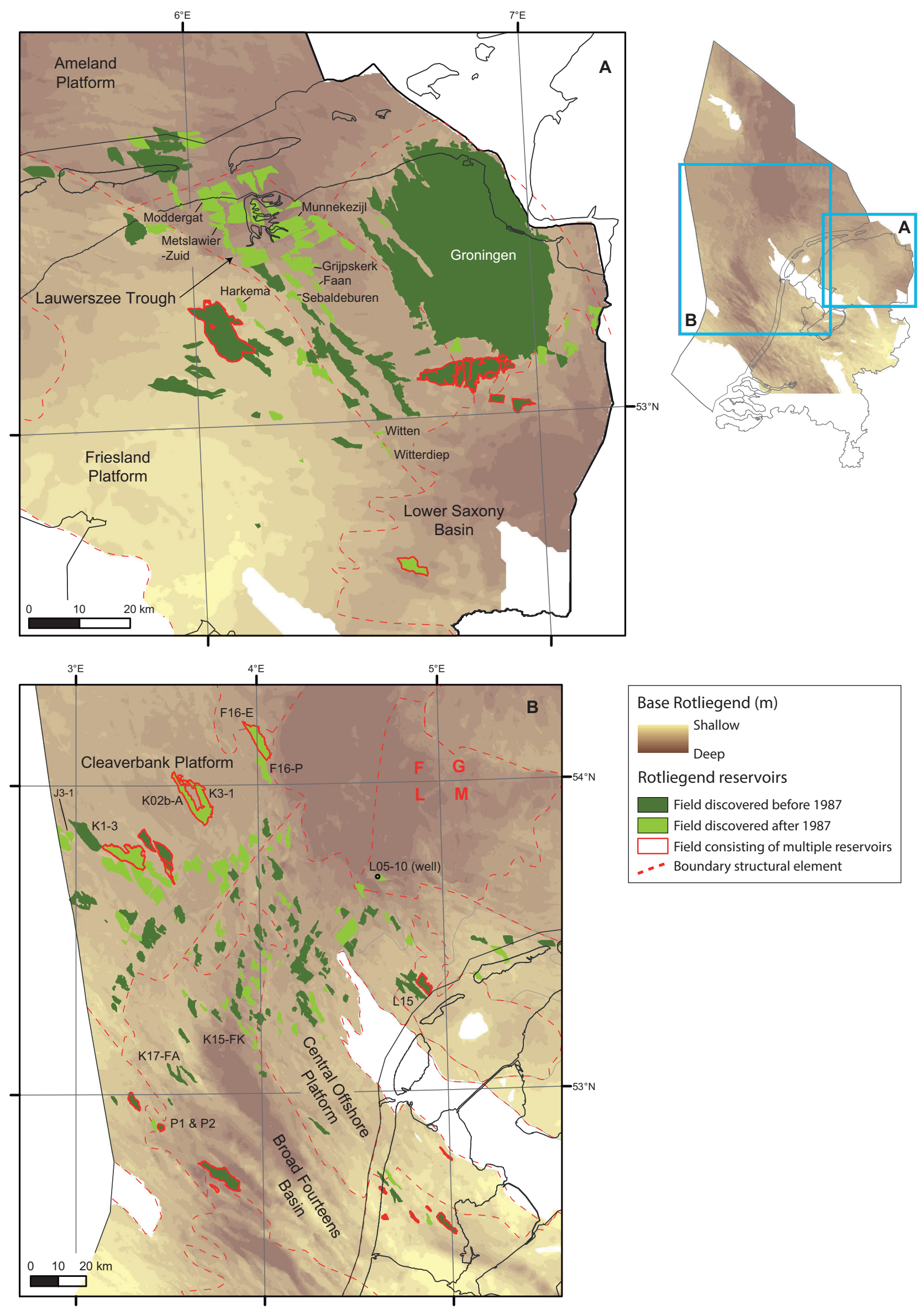

\begin{tabular}{|c|}
\hline $\begin{array}{c}\text { Base Rotliegend }(\mathrm{m}) \\
\text { Shallow } \\
\text { Deep }\end{array}$ \\
\hline Rotliegend reservoirs \\
\hline | Field discovered before 1987 \\
\hline Field discovered after 1987 \\
\hline Field consisting of multiple reservoirs \\
\hline
\end{tabular}

Fig. 4. Maps of the Rotliegend play areas showing the discoveries before and after 1987. 
sandstone reservoirs. In addition, 'tight' (low permeability) Rotliegend fields are subject of increased interest. These may contain significant volumes but the permeabilities are too low $(<1 \mathrm{mD})$ to be developed by conventional vertical wells. They require hydraulically fracked vertical wells, or horizontal underbalanced wells into higher permeability zones (Veeken, 2007). Older discoveries in these reservoirs that are now experiencing increased interest include K17-FA (2006), which is currently being produced and fields in the northern P blocks (blocks P1, P2). In the province of Friesland two wells drilled in recent years encountered gas in Rotliegend sandstones (Eernewoude-2 and Vinkega-2).

\section{Triassic}

In terms of volumes the Triassic forms the second most important play in the Netherlands, although it only works in areas where an effective Zechstein salt seal between the Westphalian source rocks and these reservoirs is lacking. This may occur locally in areas where strong salt movement led to salt withdrawal adjacent to salt domes and regionally at the southern margin of the Southern Permian Basin area (e.g. the West Netherlands Basin) where no Zechstein salt was deposited (see Ten Veen et al., this issue). Triassic gas fields in the Broad Fourteens and Lower Saxony basins and in the area surrounding the southern part of the Central Graben (Figs 5 and 6) are all related to salt withdrawal.

From the 50 Triassic accumulations found in the previous 25 years, 27 are located in and around the West and Central Netherlands Basins (onshore and offshore areas). Amongst the largest discoveries are Pernis-West, Botlek, Waalwijk, the P15P18 fields, Q1-B and Q4. In the West Netherlands Basin, hydrocarbons in the Triassic stem from two source rocks - most of the gas is charged from Westphalian coals whereas the oil originates from the stratigraphically younger Toarcian Posidonia Formation as a result of juxtaposition across faults (De Jager et al., 1996). Fluvial to aeolian sandstones in the Lower Triassic Buntsandstein (e.g. Volpriehausen, Detfurth, Röt) are the most important reservoirs. Triassic evaporites and intra-formational shales (e.g. Solling) form important seals, although locally Lower Jurassic and Cretaceous claystones are the sealing units. Additional prolific gas discoveries in Triassic sands were made in the L9 block (1993) where the Solling ('fat') sandstone turned out to be anomalously thick (De Jager, this issue) and on the Schill Grund Platform (M7-2, G14-2, G17). The Triassic still forms an excellent exploration target, for example in the southern part of the West Netherlands Basin.

\section{Carboniferous}

In the Carboniferous play gas charged from intra-formational coals is trapped in fluvio-deltaic sandstone bodies of varying dimensions. Below the Base Permian Unconformity (BPU) the

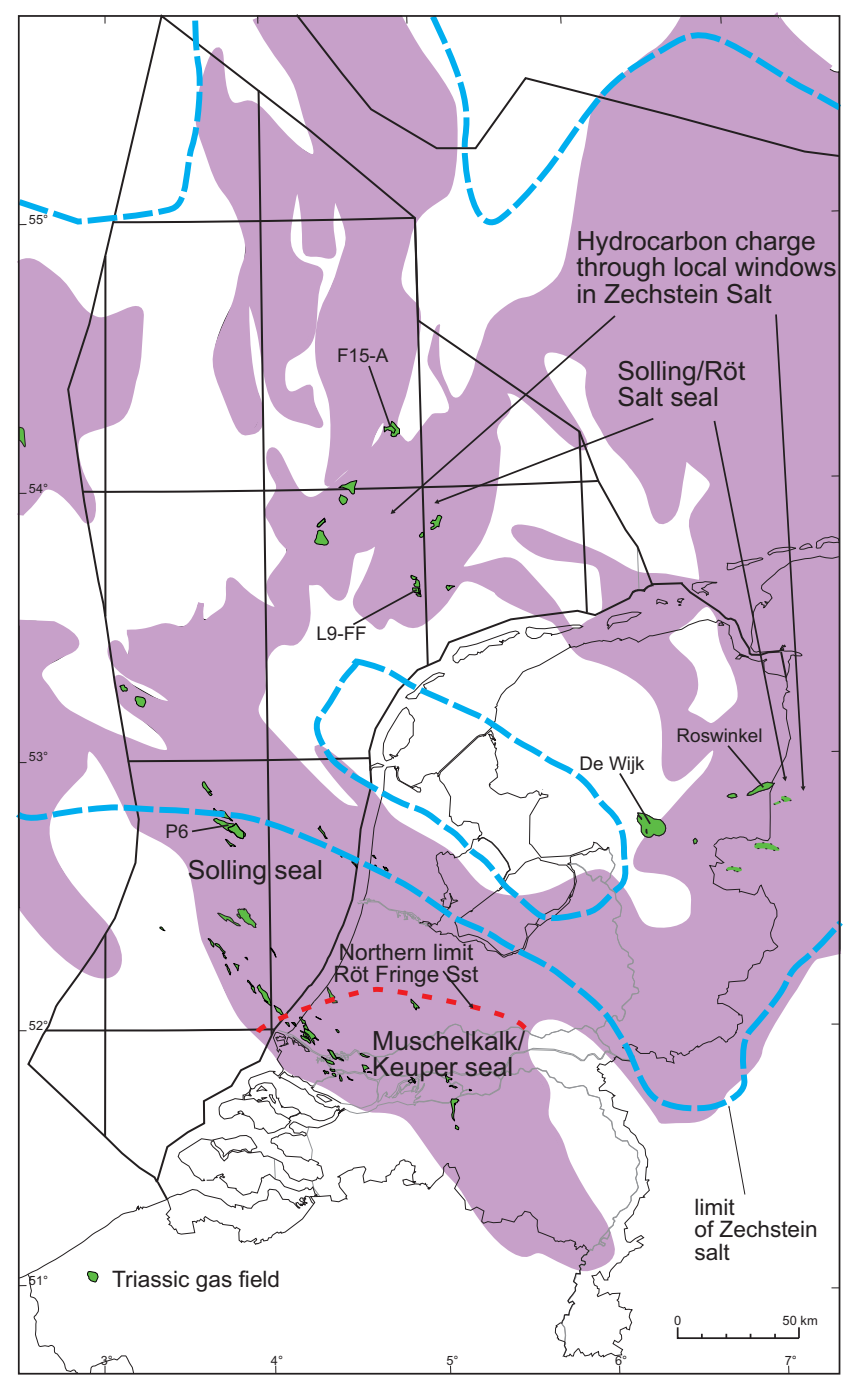

Fig. 5. Triassic play map showing gas fields producing from Triassic reservoirs and the present-day distribution of the Main Buntsandstein Subgroup (purple) and the Röt Fringe Sandstone. These units form the main reservoirs. The main top seals are indicated per area. Beyond the depositional limit of the Zechstein salt, Westphalian gas can migrate directly into Triassic reservoirs. Where the Zechstein salt is present, charge into the Triassic relies on the presence of breaches in the Zechstein as a result of salt withdrawal or faulting. The names of some of the main Triassic fields are indicated. After De Jager \& Geluk (2007).

Carboniferous succession occurs in tilted fault blocks sealed by Upper Rotliegend claystones and evaporites (Cleaverbank Platform) or by Zechstein evaporites (eastern Netherlands). Due to this unconformable relationship, stacked gas accumulations exist where gas is found in both Carboniferous sandstones and in thin Rotliegend sandstones or Zechstein carbonate reservoirs (Fig. 8).

Following the discovery of the Coevorden Carboniferous reservoir in 1951, a number of fields have been found in the northeast Netherlands onshore area (Figs 7 and 8). The Cleaverbank Platform also turned out to contain gas-bearing Carboniferous sandstones. Here, the first discovery took place in 1974 (K4-FA). 

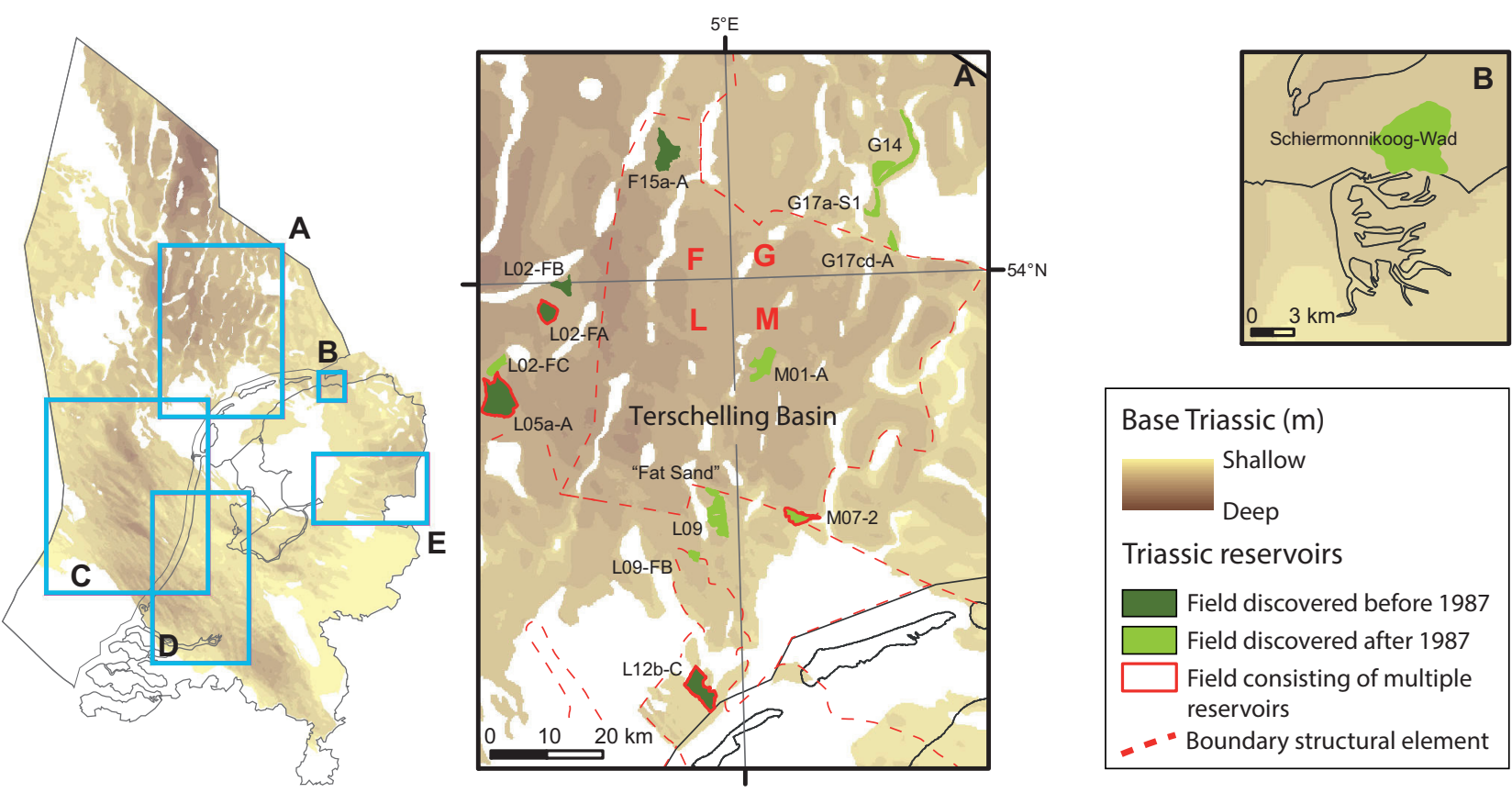

Base Triassic (m)

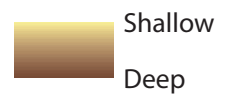

Triassic reservoirs

Field discovered before 1987 Field discovered after 1987

Field consisting of multiple reservoirs

- - Boundary structural element
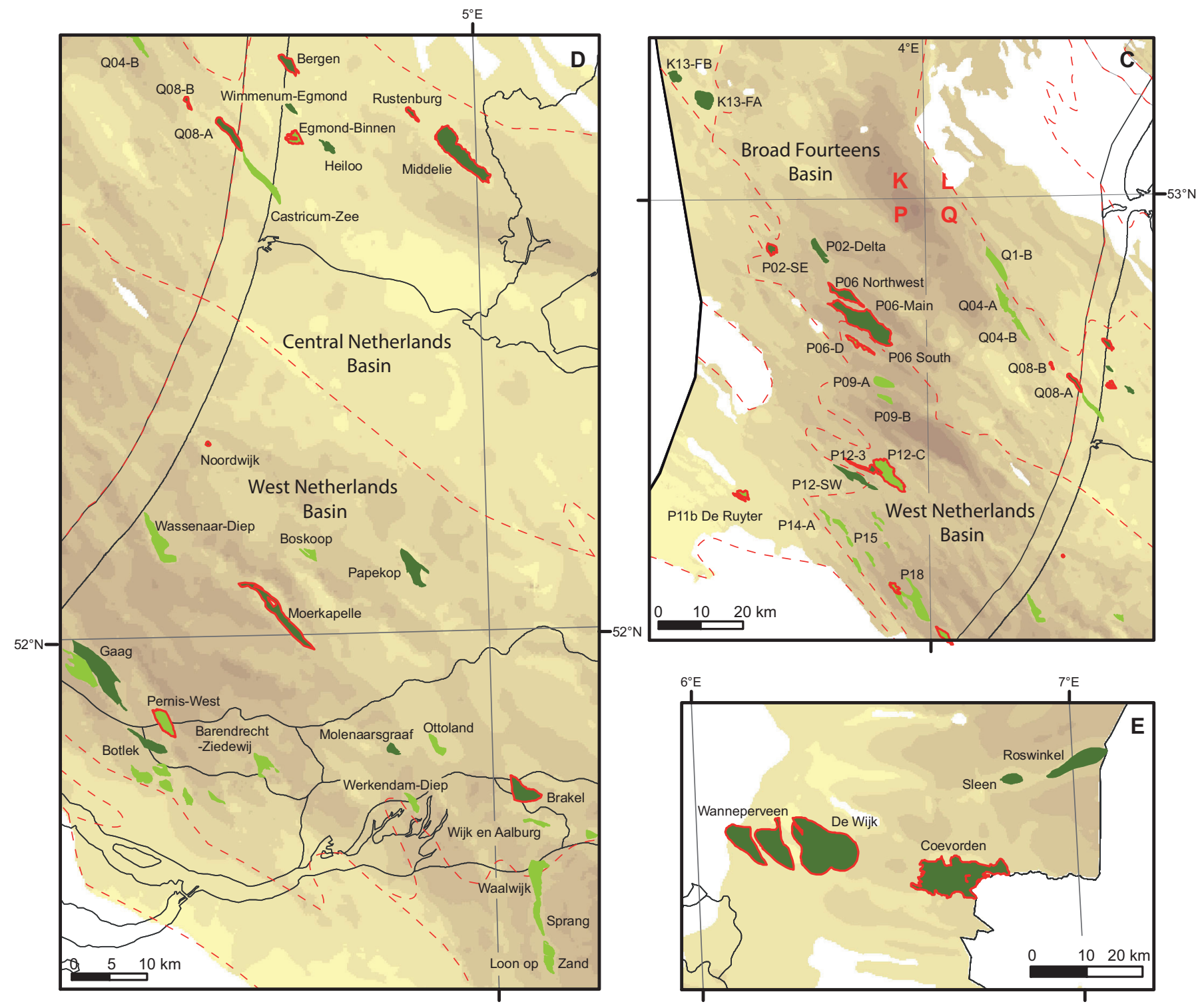

Fig. 6. Maps of the Triassic play areas showing the discoveries before and after 1987. 


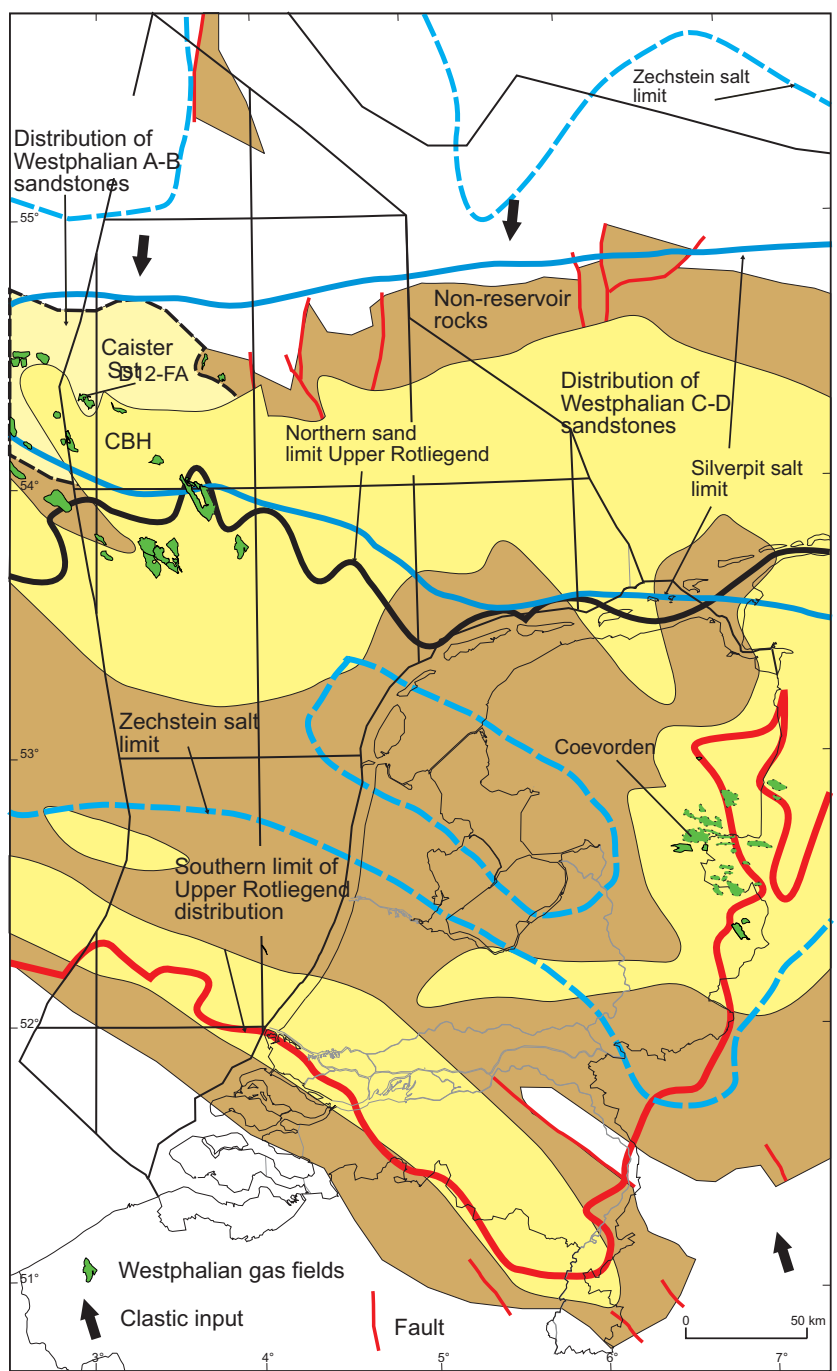

Fig. 7. Westphalian play map. This map outlines the distribution of the Westphalian reservoir rocks. The best reservoirs occur mostly in the sandprone Westphalian C and D (yellow). On the Cleaver Bank High (CBH), gas has also been discovered in Westphalian A and B reservoirs (Caister Sandstone, light yellow). The names of some of the main fields are indicated. Most gas fields producing from the Westphalian occur in traps where the Upper Rotliegend sandstones are thin or absent, and where Zechstein salt or Silverpit shales provide a seal (after De Jager \& Geluk, 2007).

In both areas, the Carboniferous is prospective because Rotliegend sandstones are very thin or absent.

In the last 25 years, the following discoveries have been made: K02b-A (1987), Hardenberg Oost (1988), K4a-D (1989), K4-A (1991), Geesbrug (1992), K5a-EN (1992), E17a-A (1996), K5a-ES (1996), D18-FA (1997), K4a-B (1997), F16-E (2001), D12-A (2002), D15-A (2004) and E18-A (2006). As reflected in the number of discoveries, the offshore Carboniferous fairway received most interest (Fig. 8B); the onshore can be considered as relatively creamed. It is particularly the northern extension of the offshore Carboniferous fairway that may still contain unrealised reserves. A critical factor is the high nitrogen contents that have been found in Carboniferous gas in the northernmost Carboniferous discoveries known to date in block E12 (see Abdul Fattah et al., this issue). In 2012, a large seismic survey was acquired covering the $\mathrm{D}, \mathrm{E}$ and $\mathrm{F}$ blocks, with the objective to further de-risk exploration in the area.

In the early 2000s a heroic effort was made to open a new onshore Pre-Westphalian play, the Dinantian limestones. In the northern Netherlands a number of large Dinantian buildups were identified on seismic data. These deep objectives had already been targeted in the 1970's in the Nagele-1 (Elf Petroland, 1970) and Tjuchem-2 wells (NAM, 1971). Those wells penetrated a significant Namurian succession, but did not reach the Dinantian buildups. More than 30 years later the same companies again drilled two wells: NAM drilled Uithuizermeeden-2 in 2001/'02 and Total drilled Luttelgeest-1 in 2004/'05. This time both wells encountered Dinantian carbonates, but these were found dry and tight (Van Hulten \& Poty, 2009; Herber \& De Jager, 2010). In the northern offshore area, where the Lower Carboniferous is mainly composed of siliciclastic rocks (Yoredale succession), the low maturity of source rocks (A-blocks), high nitrogen contents and a low sealing capacity (E-blocks) have probably inhibited discoveries so far.

\section{Cenozoic}

Production from Cenozoic reservoirs is not a recent development. Minor production from the Basal Dongen Sand took place in the IJsselmonde Field (1956) in the West Netherlands Basin. In addition, the Dongen Tuffite in the De Wijk Field (1949) formed a producing reservoir from 1955 up to the 1980s (Gdula, 1983). Due to subsidence problems production was ceased. Recently NAM applied for a permit to produce this gas again and plans to reduce subsidence through nitrogen injection in the reservoir.

Gas occurrences in Cenozoic reservoirs in the northern offshore area have been known for a long time. Gas is trapped in various sands deposited in a shallow marine setting and is sealed by intra-formational claystones. These deposits belong to the so-called Eridanos delta-system that extended over large parts of the present-day North Sea (see Benvenuti et al., this issue). Gas is either trapped structurally in subtle anticlines overlying saltdomes or stratigraphically in delta-clinoforms. Most of the gas fields consist of several gas-bearing reservoir levels, clearly indicated by stacked bright spots on seismic data. The trapped gas is thought to be sourced both from deeper source rocks (evidenced by gas-chimneys, probably from Carboniferous coals or from in-situ biogenic gas production; Schroot et al., 2005). Until recently, the gas has mostly been treated as an exploration risk rather than a resource. Economic production from shallow reservoirs is therefore a new aspect of the petroleum geology in the Netherlands. The first large scale economic gas production from a Cenozoic reservoir started in the northern offshore in 2007 from the A12-FA Field. This field is located in a cluster of so-called shallow gas fields in the A and B quadrants (Fig. 9). 


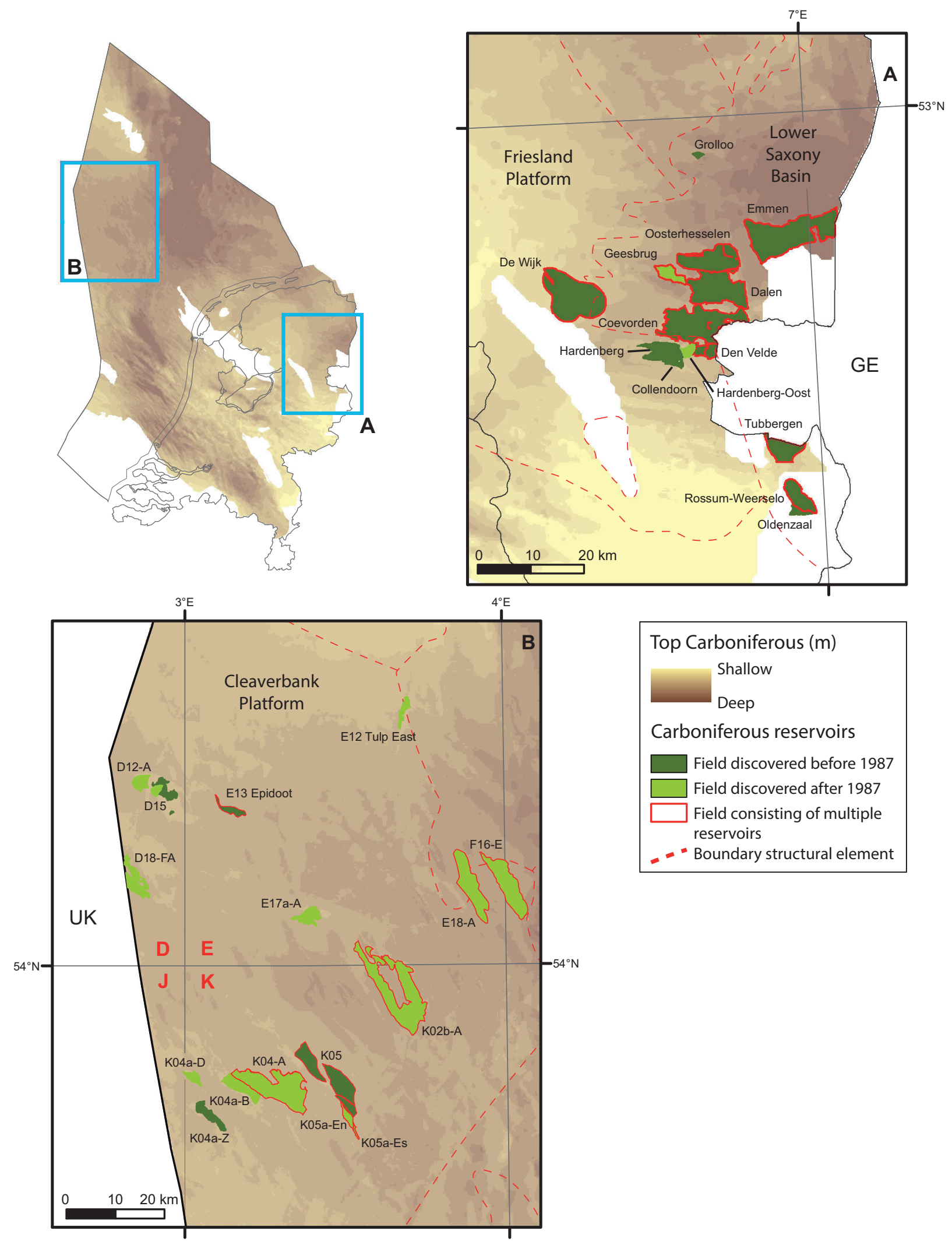

Fig. 8. Maps of the Carboniferous play areas showing the discoveries before and after 1987.

There are four additional shallow gas accumulations to be developed in the next few years (A15-A, A18-FA, B13-FA and B17-FA). Ongoing studies focus on a better understanding of the architecture of the depositional system and the related distribution of reservoirs parameters. In German, UK and Danish waters there is interest in shallow gas too, but no economic volumes have been reported yet. 


\section{Upper Jurassic - Lower Cretaceous}

The Upper Jurassic - Lower Cretaceous hydrocarbon play is the oldest one in the Netherlands (Schoonebeek oil field, 1943). Subsequent discoveries were made in the West Netherlands and Broad Fourteens Basin (oil) and on the Friesland Platform (gas).
Various shallow marine (locally deltaic or fluvial) sandstones form the main reservoirs, which are commonly sealed by transgressive claystones. The clastic reservoirs have mostly been deposited within the Jurassic rift basins, except from the transgressive sandstone reservoirs of the Vlieland Formation which were also deposited over the platform areas (Fig. 10a). In
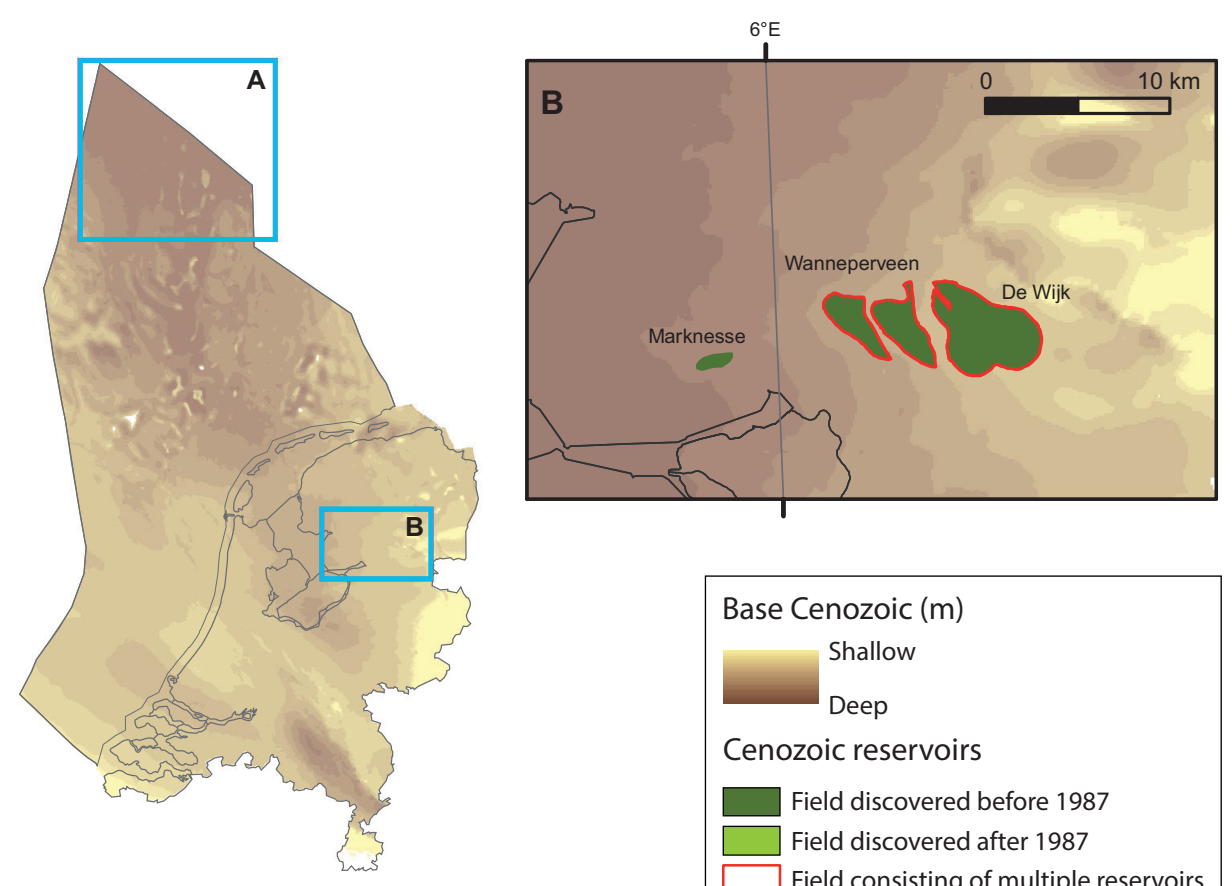

\section{Cenozoic reservoirs}

Field discovered before 1987

Field discovered after 1987

Field consisting of multiple reservoirs

Boundary structural element

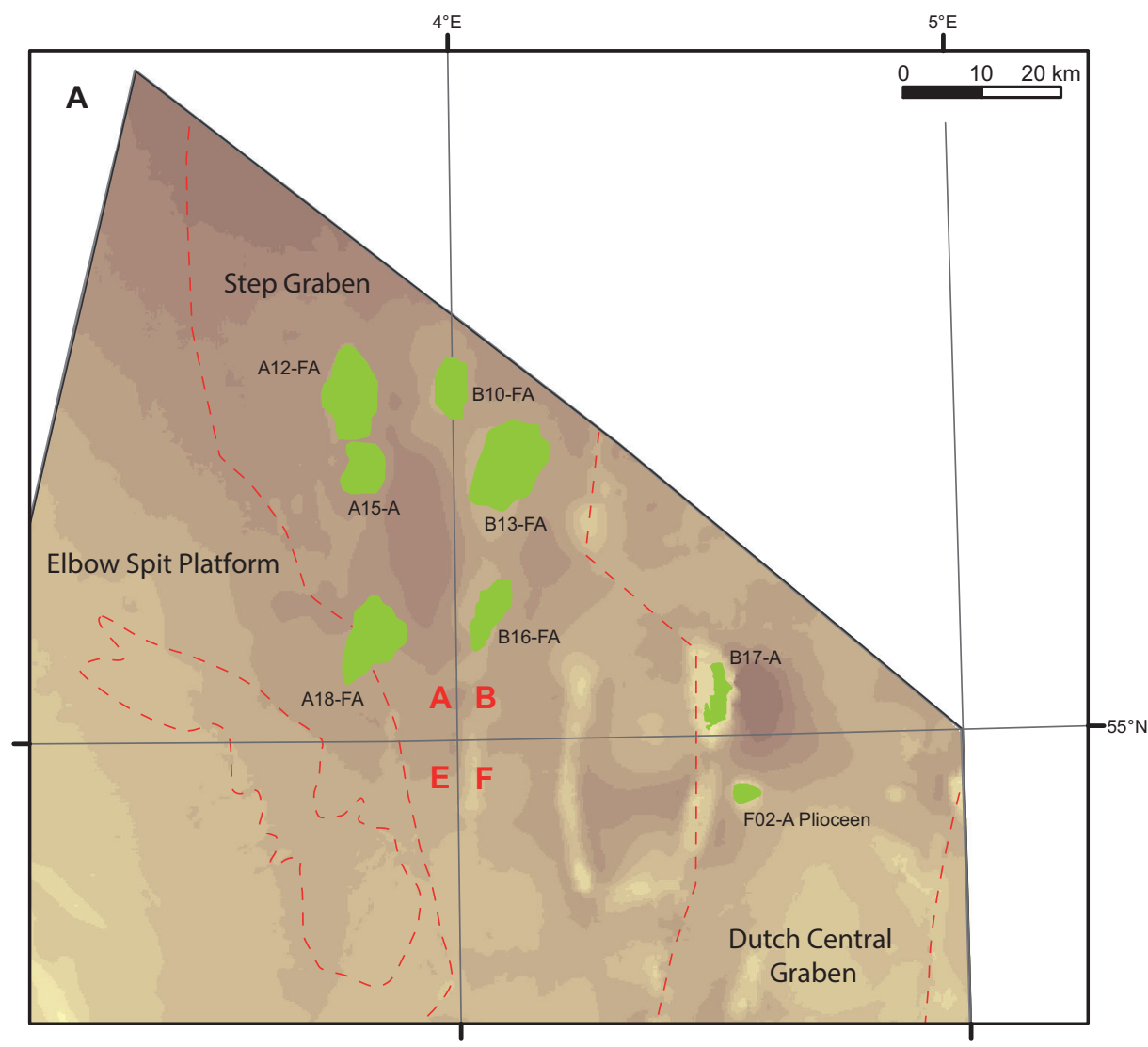

Fig. 9. Maps of the Cenozoic play areas. All discoveries in the northern offshore were made post 1987. 

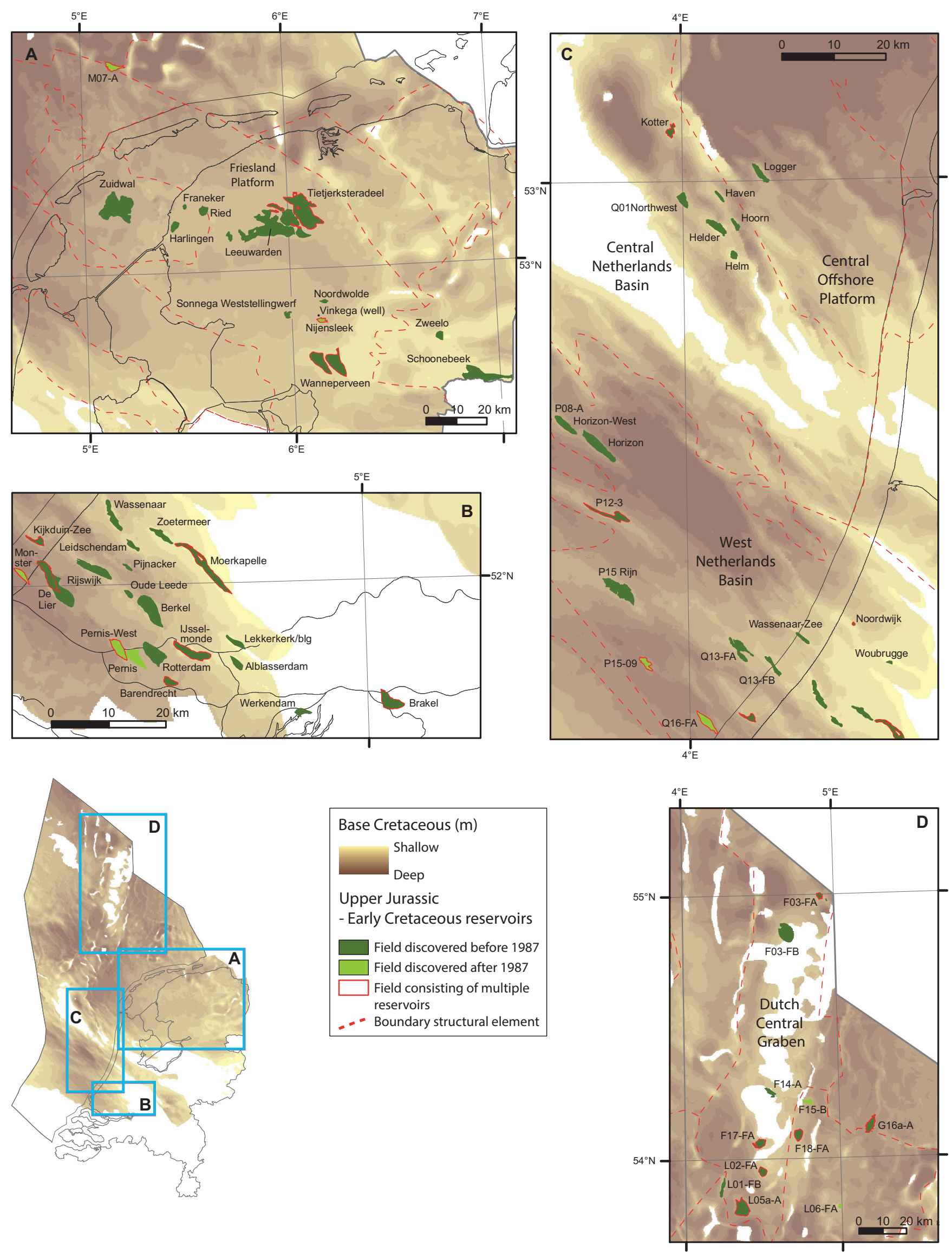

Fig. 10. Maps of the Jurassic-Lower Cretaceous play areas showing the discoveries before and after 1987. 
the West Netherlands Basin, the main trap style is a four-way dip closure related to inversion anticlines; the Central Graben typically shows turtle-back structures and tilted fault blocks (De Jager \& Geluk, 2007).

Oil is sourced from the Jurassic Posidonia shale, which also explains the concentration of fields in the former Jurassic graben areas such as the Central Graben, the West Netherlands and Broad Fourteens basins where the Posidonia shale has been preserved and is currently oil-mature. An exception to this is the Schoonebeek Field, which is sourced from Lower Cretaceous laminated lacustrine mudstones ('paper shales') of Berriasian age, deposited in the Lower Saxony Basin. Gas is thought to be sourced from Carboniferous rocks mainly (De Jager \& Geluk, 2007).

During the last 25 years only a few new fields have been found (Fig. 10): Pernis (1989), L6-FA (1990), F15-B (1998) and
Nijensleek (1987). Some fields have a secondary Upper Jurassic - Lower Cretaceous reservoir, for example M7-A (1996). These fields together added some $5 \mathrm{Bcm}$ of reserves.

An interesting and recent aspect is the redevelopment of the Schoonebeek oil field. After 48 years of production, the field was abandoned in 1996. Thanks to high oil prices and technological breakthroughs, NAM decided to start production again following an extensive 73-wells drilling campaign and the establishment of a steam injection facility. In 2011 the last well was drilled and production will probably continue for the next 25 years. Another aspect worth to mention is recent exploration activity in the south of the province of Friesland, where gas has been found in the Vlieland sandstone reservoir (Vinkega-1; Fig. 10).

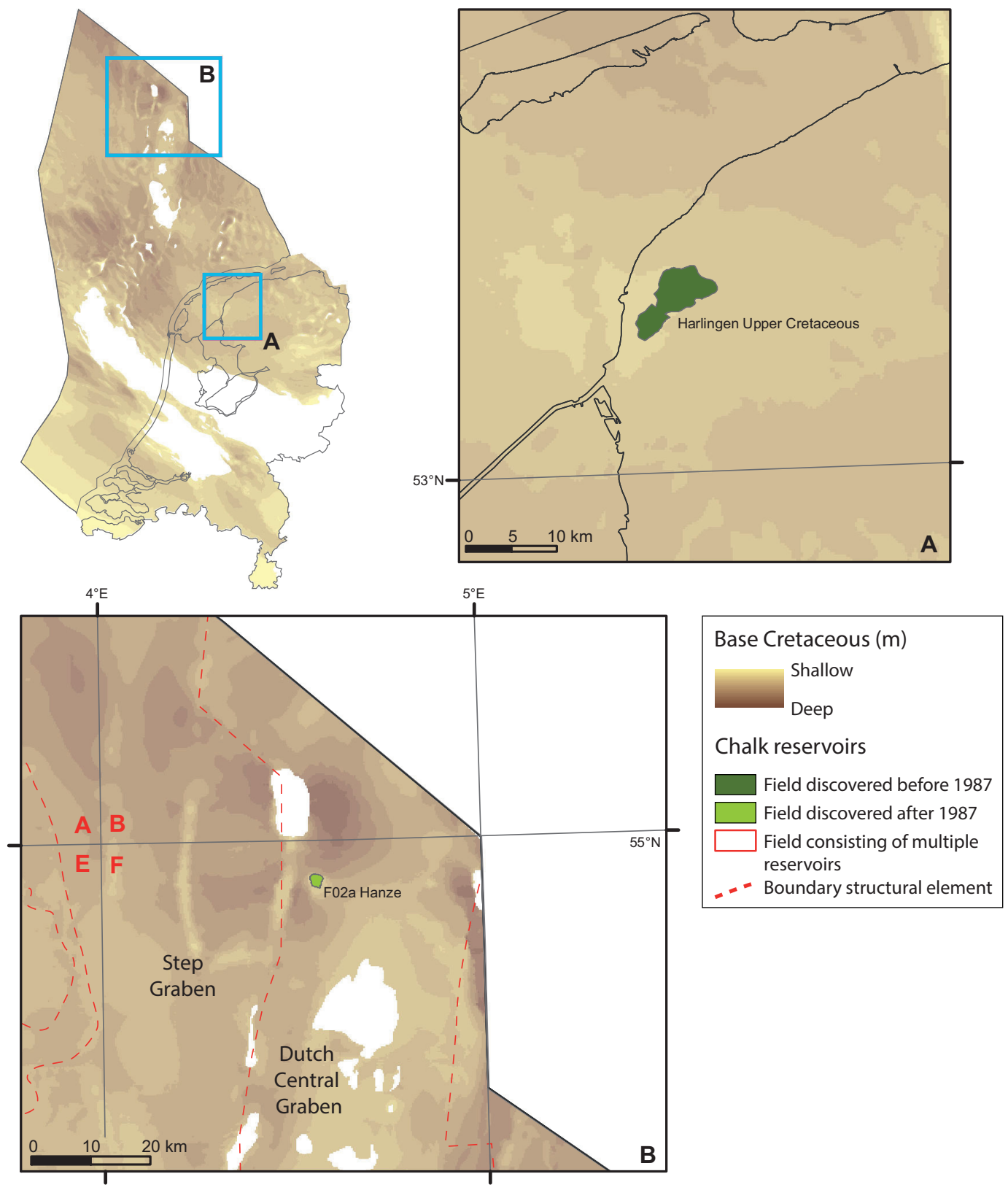

Fig. 11. Maps of the Chalk discoveries. The F2 oil field is the only discovery of the past 25 years. 


\section{Chalk}

In contrast to Denmark and Norway, the Chalk in the Netherlands is not a very prolific succession so far. De Jager \& Geluk (2007) suggest that poor sealing capacities of Paleogene claystones prevented effective trapping in the Chalk, in addition to local overpressuring. In 1949 the first hydrocarbon-bearing reservoir was encountered in the De Wijk Field. The Harlingen Field (discovered in 1964) was the only producing onshore field, but has been temporarily stopped due to higher than expected subsidence. Until very recently, the only Chalk discovery in the last 25 years was the Hanze oil field (1996) in the F2 block, sourced by the Posidonia shale (Central Graben; Fig. 11). This field contains some $120 \mathrm{MMbbl}$ of oil reserves. However, in December 2012 Wintershall Noordzee announced the discovery of another Chalk oil field in the F17 block (well F17-10). Recoverable volume for this field has been estimated at $30 \mathrm{MMbbl}$, with significant upside. Both the Hanze field and the discovery in block F17 are located on top of a Zechstein salt dome.

\section{Zechstein}

Most Zechstein gas fields are reservoired in the platform and slope carbonates that fringe the southern margin of the Southern Permian Basin (Fig. 12). Since 1955 several fields have been discovered. Most of the traps are fault - dip closures. In the G16a-A gas field, production is from the Zechstein caprock on top of a saltdome.

About 17 fields have been found in Zechstein carbonates from 1987 onward, of which some only form a secondary reservoir in the Zechstein (Fig. 13). Most are located in the NE onshore area (e.g. Collendoornerveen, 1990; Hoogenweg, 1988; De Blesse, 1987 and Nijensleek, 1987). The majority of the Zechstein fields discovered post 1987 has either not taken in production yet or was shut in already. Zechstein discoveries have added around $5 \mathrm{Bcm}$ of gas reserves over the last 25 years.

\section{Underground storage}

The last years have seen a further diversification of underground storage. At the onset of 20115 licenses were issued for underground gas storage (Alkmaar, Bergermeer, Grijpskerk, Norg and Zuidwending), two for nitrogen storage (Winschoten II en Winschoten III), one for liquid hydrocarbons (Twenthe-Rijn De Marssteden) and one for salt water (Zevenbergen). Most of the underground gas storage facilities are in depleted Rotliegend gas fields, apart from Alkmaar and Zuidwending which reside in respectively Zechstein carbonates and salt caverns. According to the Ministry of Economic Affairs the 2010 stored gas volume was $6 \mathrm{Bcm}$, and the extracted gas $4 \mathrm{Bcm}$. The nitrogen and liquid hydrocarbon storage facilities are in rock salt caverns.

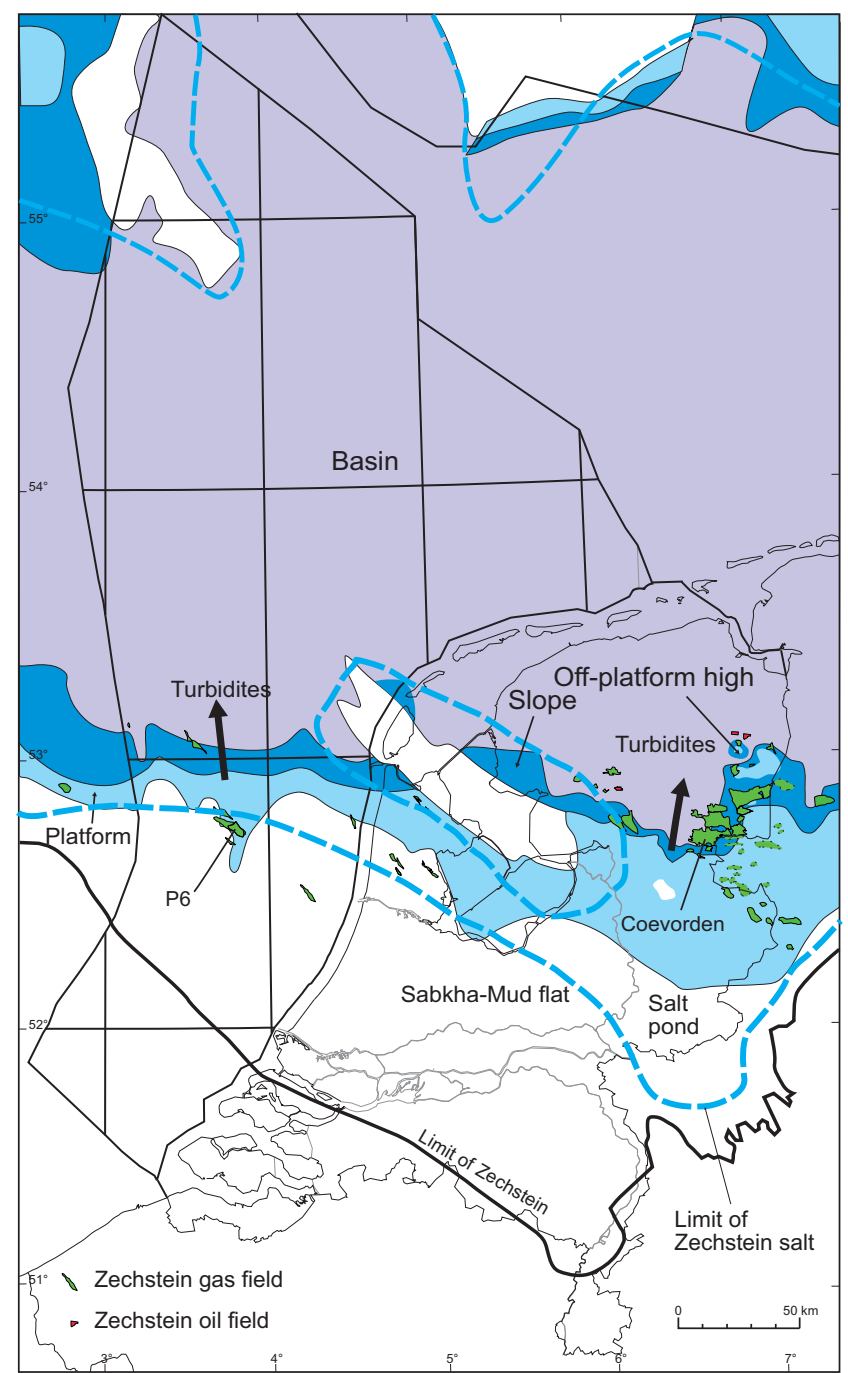

Fig. 12. Zechstein play map. Shown is the paleogeographic map of the Z2 Carbonate, which constitutes the main Zechstein reservoir in platform facies. Gas accumulations in the western offshore, located south of the distribution area of this carbonate, are in the Z3 Carbonate (after De Jager \& Geluk, 2007).

\section{Coal}

Several coal-mining licenses still exist in the southern part of the Netherlands (Fig. 2c) where the coal-bearing Carboniferous is at mineable depth. During the last 25 years the possibility to extract adsorbed methane (Coal Bed Methane, CBM) from coal layers has been studied extensively. No CBM exploration wells were drilled in the Netherlands, but one well in the adjacent part of Belgium (Peer, KB-206) and two wells in Germany in the 1990 's tested the CBM potential. None of these wells offered sufficient encouragement to continue CBM exploration at the time. The main reason for this may be that the Carboniferous coals are relatively thin compared to areas where CBM is successfully produced (e.g. Australia, China, South Africa). 

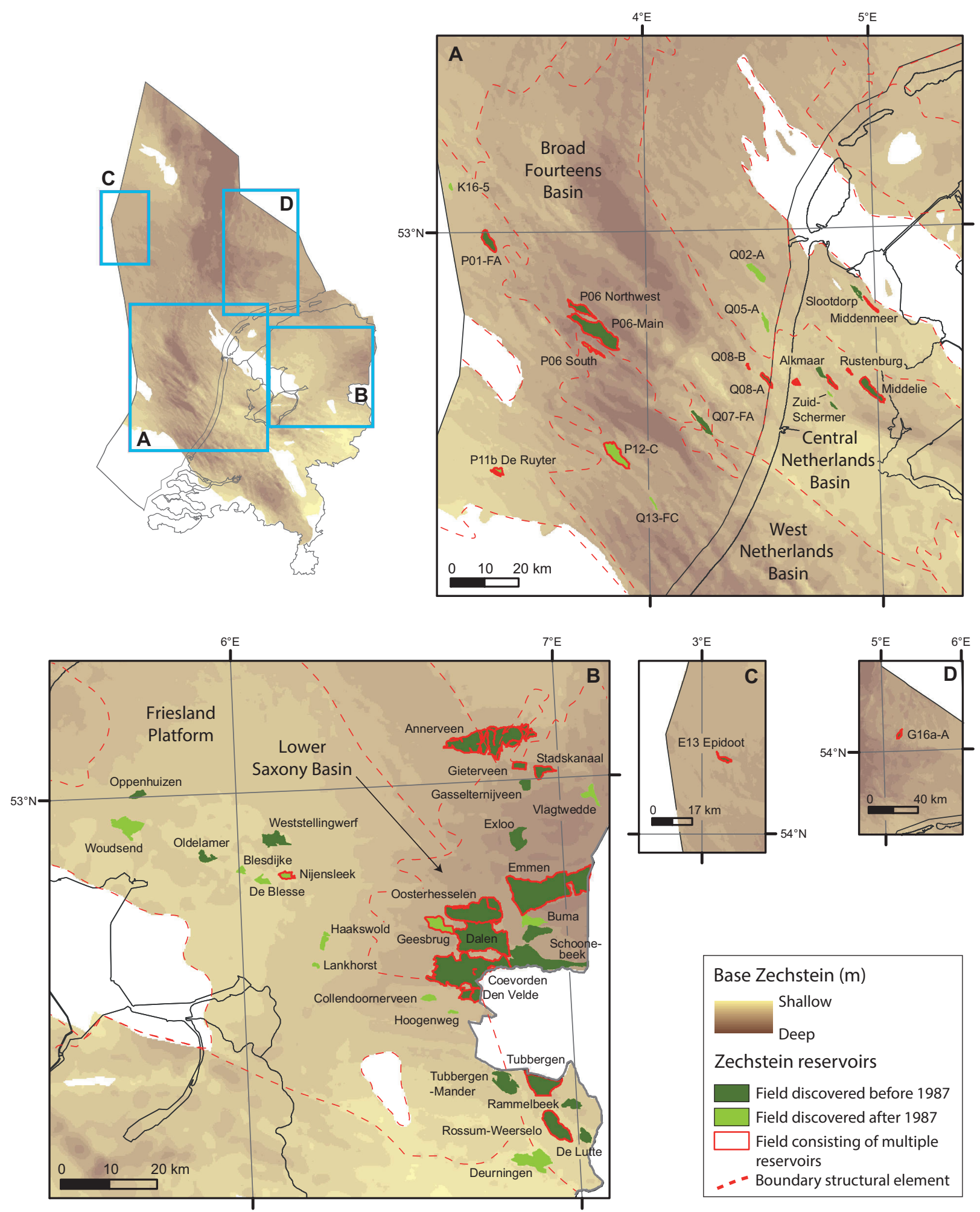

Fig. 13. Detailed maps of the Zechstein play areas showing the discoveries before and after 1987.

\section{Shale gas}

A new trend in the oil and gas sector is the production of gas from tight rocks such as shales. In order to enable an economic flow rate, long horizontal wells are drilled in the shales, followed by hydraulic fracturing (fracking). This has proven to be an economic production technique in the United States. Worldwide there is a lot of interest in areas with shale gas potential. In the Netherlands, both the Namurian and the Jurassic Posidonia shales are considered as potential targets for shale gas exploration. Plans exist aims to drill wells in the southern Netherlands (near Boxtel and Alphen) and in the Noordoostpolder to test the 
shale gas potential of these areas. Only moderate recoverable volumes are expected in the Netherlands since the surface constraints are likely to prevent drilling a large number of wells (Herber \& De Jager, 2010).

\section{Non-hydrocarbons}

\section{Salt mining}

In the last 25 years salt production in the Netherlands did not change significantly, apart from areal extensions of some production licenses. Most production license pre-date 1987 and target either Triassic Röt or Zechstein salts. The youngest production license is Barradeel, Friesland, which was granted in 1991. In Barradeel, Zechstein salt is being mined by solution mining. This solution mining at depths between 2500 and $3000 \mathrm{~m}$ is the deepest salt production world-wide. The large depth of mining has both positive and negative effects. In a positive sense the time to saturate the brine is much reduced thanks to the high temperatures - salt can be produced after several months compared to 1-2 years in caverns at shallower depths. The negative effects are caused by the (unexpected) rapid convergence of the caverns and related subsidence at the surface. After several years it was noted that subsidence was 20 -fold stronger than anticipated. Within 10 years the limit of $35 \mathrm{~cm}$ had been reached - a marked contrast to the modelled amount of $8 \mathrm{~cm}$. The scheduled production life of the caverns in the Barradeel concession will therefore be much shorter than planned with a much lower salt production rate.

In order to secure future supply from the Twente region, Akzo Nobel drilled the exploration well Isidorushoeve-1 in 2011 near the village of Haaksbergen to test the Zechstein salt. If the salt proves to be of good quality, this would add a new and possibly significant salt resource to the existing Röt salt in their concession Twenthe-Rijn.

\section{Geothermal energy}

The first well in the Netherlands to explore deep geothermal energy was Asten-2 (1987), located in the Roer Valley Graben (Heederik \& Huurdeman, 1988). The reservoir quality of the Cenozoic reservoirs, however, did not warrant economic production of water at the time. Due to high gas prices and the discussion about reducing the emission of greenhouse gases, geothermal energy again gained interest in recent years.

The first operational project that aimed at using deep geothermal energy is the so-called Heerlen Mijnwater project in the southern part of Limburg (2006). In this project water from abandoned mines, at depths of around $700 \mathrm{~m}$, is used for heating and cooling of buildings. Subsequently, in 2007, the wells Van den Bosch-1 and 2 were the first deep geothermal wells that came on stream as a doublet to warm greenhouses in the area near Bleiswijk in the western part of the Netherlands.
Since then, a rush on geothermal exploration licenses took place (93 applications as per August 2011; Fig.2).

The greatest concentration of exploration permit applications is located in the West Netherlands Basin. Here, Lower Cretaceous sandstones form a potentially good reservoir close to 'the market'. Another advantage of the West Netherlands Basin is the high density of oil and gas wells and seismic data, which decrease exploration risks. However, production of minor amounts of oil in the Pijnacker geothermal wells (2010) and gas in the Den Haag geothermal wells (2010) shows that unexpected and unwanted findings can still happen. Legally this is a complicated matter since these resources are not regulated for in the geothermal license, and it is the owner of the hydrocarbon license who is the rightful owner of any hydrocarbons encountered.

Capitalising on the success in the West Netherlands Basin, other parts of the Netherlands received interest for geothermal energy production as well (Fig. 2). In 2011, a successful doublet was drilled in the Koekoekspolder near the city of Kampen. The temperatures in the Rotliegend reservoir were even higher than expected $\left(>70^{\circ} \mathrm{C}\right)$. In the northern part of the Netherlands, the Rotliegend may also be a target, despite the presence of many gas fields. In the southeastern part of the Netherlands, near Venlo, a well has been drilled in order to test the Lower Carboniferous limestones as a potential reservoir. According to several websites the results of these wells have exceeded expectations, which is a very interesting result for a region where exploration activity has been very limited so far.

\section{Acknowlegdements}

The authors greatly appreciated the comments provided by Jan de Jager in multiple stages of the manuscript. Carla Elmers is thanked for her work on many figures in this paper.

\section{References}

Abdul Fattah, R., Verweij, J.M., Witmans, N. \& Ten Veen, J.H., 2012. Reconstruction of burial history, temperature, source rock maturity and hydrocarbon generation in the northwestern Dutch offshore. Netherlands Journal of Geosciences 91-4: 535-554, this issue.

Benvenuti, A., Kombrink, H., Ten Veen, J.H., Munsterman, D.K., Bardi, F. \& Benvenuti, M., 2012. Late Cenozoic shelf delta development and Mass Transport Deposits in the Dutch offshore area - results of 3D seismic interpretation. Netherlands Journal of Geosciences 91-4: 591-608, this issue.

Bonté, D., Van Wees, J.-D. \& Verweij, J.M., 2012. Subsurface temperature of the onshore Netherlands: new temperature dataset and modelling. Netherlands Journal of Geosciences 91-4: 491-515, this issue.

Brouwer, G.C. \& Coenen, M.J., 1968. Nederland = Aardgasland. Roelofs van Goor (Amersfoort), $301 \mathrm{pp}$.

De Jager, J., 2012. The discovery of the Fat Sand Play (Solling Formation, Triassic), Northern Dutch offshore - a case of serendipity. Netherlands Journal of Geosciences 91-4: 609-619, this issue. 
De Jager, J., Doyle, M.A., Grantham, P.J. \& Mabillard, J.E., 1996. Hydrocarbon habitat of the West Netherlands Basin. In: Rondeel, H.E., Batjes, D.A.J. \& Nieuwenhuijs, W.H. (eds): Geology of gas and oil under the Netherlands. Kluwer Academic Publishers (Dordrecht): 191-210.

De Jager, J. \& Geluk, M.C., 2007. Petroleum geology. In: Wong, T.E., Batjes, D.A.J. \& De Jager, J. (eds): Geology of the Netherlands. Royal Netherlands Academy of Arts and Sciences (KNAW) (Amsterdam): 241-264.

Doornenbal, J.C. \& Stevenson, A.G. (eds), 2010. Petroleum Geological Atlas of the Southern Permian Basin Area. EAGE Publications b.v. (Houten), 342 pp.

Duin, E.J.T., Doornenbal, J.C., Rijkers, R.H.B., Verbeek, J.W. \& Wong, T.E., 2006. Subsurface structure of the Netherlands; results of recent onshore and offshore mapping. Netherlands Journal of Geosciences 85: 245-276.

Gdula, J.E., 1983. Reservoir geology, structural framework and petrophysical aspects of the De Wijk gas field. Geologie en Mijnbouw 62: 191-202.

Geluk, M.C. \& De Jager, J., 2012. Exploiting our riches - significance of Dutch industry. In: Floor, P. (ed.): Dutch Earth Sciences - Development and Impact. KNGMG (The Hague): 207-230.

Glennie, K.W., 2001. Exploration activities in the Netherlands and North-West Europe since Groningen. Netherlands Journal of Geosciences 80: 33-53.

Grötsch, J. \& Gaupp, $\boldsymbol{R}$. (eds), 2011. The Permian Rotliegend of the Netherlands. Society for Sedimentary Geology (Tulsa) USA, $21 \mathrm{pp}$.

Heederik, J.P. \& Huurdeman, A.J.N., 1988. Geothermal study of the Central Graben (North Brabant): evaluation of the results of an exploratory geothermal well in Asten. In: Hooghart, J.C. (ed.): Geothermal energy and heat storage in aquifers. TNO Communication on Hydrological Research (The Hague): 77-95.

Herber, R. \& De Jager, J., 2010. Oil and gas in the Netherlands - Is there a future? Netherlands Journal of Geosciences 89: 91-107.

Knaap, W.A. \& Coenen, M.J., 1987. Exploration for oil and natural gas. In: Visser, W.A., Zonneveld, J.I.S. \& Van Loon, A.J. (eds): Seventy-five years of geology and mining in the Netherlands (1912-1987). Royal Geological and Mining Society of the Netherlands (KNGMG) (The Hague): 207-230.

Kombrink, H., Doornenbal, J.C., Duin, E.J.T., Den Dulk, M., Van Gessel, S.F., Ten Veen, J.H. \& Witmans, N., 2012. New insights into the geological structure of the Netherlands; results of a detailed mapping project. Netherlands Journal of Geosciences 91-4: 419-446, this issue.

Kramers, L., Van Wees, J.-D., Pluymaekers, M.P.D., Kronimus, A. \& Boxem, T., 2012. Direct heat resource assessment and subsurface information systems for geothermal aquifers; the Dutch perspective. Netherlands Journal of Geosciences 91-4: 637-649, this issue.

Munsterman, D.K., Verreussel, R.M.C.H., Mijnlieff, H.F., Witmans, N., KerstholtBoegehold, S. \& Abbink, O.A., 2012. Revision and update of the CallovianRyazanian Stratigraphic Nomenclature in the northern Dutch offshore, i.e. Central Graben Subgroup and Scruff Group. Netherlands Journal of Geosciences 91-4: 555-590, this issue.

Nelskamp, S., Verweij, J.M. \& Witmans, N., 2012. The role of salt tectonics and overburden in the generation of overpressure in the Dutch North Sea area. Netherlands Journal of Geosciences 91-4: 517-534, this issue.

Pluymaekers, M.P.D., Kramers, L., Van Wees, J.-D., Kronimus, A., Nelskamp, S., Boxem, T. \& Bonté, D., 2012. Reservoir characterisation of aquifers for direct heat production: Methodology and screening of the potential reservoirs for the Netherlands. Netherlands Journal of Geosciences 91-4: 621-636, this issue.
Schroot, B.M., Klaver, G.T. \& Schüttenhelm, R.T.E., 2005. Surface and subsurface expressions of gas seepage to the seabed - examples from the Southern North Sea. Marine and Petroleum Geology 22: 499-515.

Ten Veen, J.H., Van Gessel, S.F. \& Den Dulk, M., 2012. Thin- and thick-skinned salt tectonics in the Netherlands; a quantitative approach. Netherlands Journal of Geosciences 91-4: 447-464, this issue.

Van Hulten, F. \& Poty, E., 2009. Dinantian Reefs underneath the Netherlands. $71^{\text {st }}$ EAGE Conference \& Exhibition (Amsterdam).

Van Wees, J.-D., Kronimus, A., Van Putten, M., Pluymaekers, M.P.D., Mijnlieff, H., Van Hooff, P., Obdam, A. \& Kramers, L., 2012. Geothermal aquifer performance assessment for direct heat production - Methodology and application to Rotliegend aquifers. Netherlands Journal of Geosciences 91-4: 651-665, this issue.

Veeken, C.A.M., Van Velzen, J.G.F., Van den Beukel, J., Lee, H.M., Hakvoort, R.G., Hollman, F.J., Evans, C. \& Okkerman, J.A., 2007. Underbalanced drilling and completion of sand-prone tight gas reservoirs in Southern North Sea. European Formation damage conference (Scheveningen, the Netherlands).

Verweij, J.M., Simmelink, H.J., Underschultz, J. \& Witmans, N., 2012. Pressure and fluid dynamic characterisation of the Dutch subsurface. Netherlands Journal of Geosciences 91-4: 465-490, this issue.

Wong, T.E., Batjes, D.A.J. \& De Jager, J. (eds), 2007. Geology of the Netherlands. Royal Netherlands Academy of Arts and Sciences (KNAW) (Amsterdam), 354 pp. 